\title{
Analysis of the Impact of IFRS on Net Worth of Anonymous Companies
}

\author{
Irene Buele*, Esthefany Sarmiento, Diana Arce \\ Universidad Politecnica Salesiana, Ecuador \\ *Corresponding author: ibuele@ups.edu.ec
}

\begin{abstract}
The adoption of International Financial Reporting Standards (IFRS), for recording the economic and financial operations of companies worldwide, makes a great difference in the usefulness and applicability of accounting information. Before this process, the Superintendencia de Compañías, Valores y Seguros of Ecuador, has published resolutions for the gradual application to IFRS since 2009. The transition period began in 2010 and ended in 2012. The research analyzed the effects caused to the Net Worth in a group of Ecuadorian companies based on the Positive Theory of Accounting. This analysis determined that the most affected financial accounts in the Process of transition to Property were Plant and Equipment, Intangible Assets and Obligations with Non-Current Financial Institutions.
\end{abstract}

Keywords: international financial reporting standards, net worth, international accounting standards, financial impact

Cite This Article: Irene Buele, Esthefany Sarmiento, and Diana Arce "Analysis of the Impact of IFRS on Net Worth of Anonymous Companies.” Journal of Finance and Accounting, vol. 6, no. 1 (2018): 1-8. doi: 10.12691/jfa-6-1-1.

\section{Introduction}

Estupiñán [1] notes that the International Financial Reporting Standards (IFRS) were issued since 2003 by the International Accounting Standards Board (IASB). These standards, IFRS (International Financial Reporting Standard), "establish the recognition, measurement, presentation and disclosure requirements that relate to transactions and events that are material to general purpose financial statements" ([2], p.156).

The companies worldwide adopted the IFRS in their accounting and financial operations, therefore, in Ecuador, the Superintendencia de Compañías, Valores y Seguros published the following resolutions for its implementation:

- According to Resolution No. 06.Q.ICI.004 issued on August 21, 2006, it stipulates that the International Financial Reporting Standards (IFRS) have mandatory application by entities subject to control and supervision of the Superintendencia de Compañías, Valores y Seguros, for the recording, preparation and presentation of financial statements, from January 1, 2009.

- According to Resolution No. 08.G.DSC.010 issued on November 20, 2008, it stipulates the schedule for the mandatory application of International Financial Reporting Standards (IFRS) by companies and entities subject to control and supervision of the Superintendence.

- In fact, companies and entities subject to control and supervision of the Superintendencia de Compañías, Valores y Seguros had to adopt IFRS in the transition process under the following schedule:

Table 1. Schedule of mandatory application of IFRS

\begin{tabular}{|c|c|c|}
\hline JANUARY 1, 2010 & JANUARY 1, 2011 & JANUARY, 12012 \\
\hline $\begin{array}{l}\text { Companies and entities subject and regulated by } \\
\text { the Securities Market Law, as well as all } \\
\text { companies that perform external audit activities. } \\
2009 \text { is established as the transition period. }\end{array}$ & $\begin{array}{l}\text { Companies with total assets either equal or greater } \\
\text { than US } \$ 4,000,000 \text { as of December } 31,2007 \text {. } \\
\text { Holding companies or holders of shares, which have } \\
\text { formed business groups voluntarily. Companies of } \\
\text { mixed economy and those that, under the juridical } \\
\text { form of companies, constitute the State and Entities } \\
\text { of the Public Sector. The branches of foreign } \\
\text { companies or other foreign state, parastatal, private } \\
\text { or mixed companies that are organized as juridical } \\
\text { persons and the associations that they form and } \\
\text { those that carry out their activities in Ecuador. } \\
2010 \text { is established as the transition period. }\end{array}$ & $\begin{array}{l}\text { Other companies that are not considered in } \\
\text { the two previous groups. } \\
2011 \text { is established as the transition period. }\end{array}$ \\
\hline
\end{tabular}

Source: Self elaboration with data obtained from the Superintendencia de Compaías, Valores y Seguros. 
The companies mentioned in the chart above must additionally elaborate, in their respective transition periods, the following:

- "Conciliations of net worth reported under NEC with worth under IFRS, as of January 1 and December 31 of the transition periods.

- Conciliations of the 2009, 2010, and 2011 income statement, as the case may be, under NEC with the income statement under IFRS.

- Explain any material adjustments if any to the cash flow statement of 2009, 2010 and 2011, as the case may be, previously submitted under NEC" [3].

The mandatory application of IFRS affected around 2,366 active companies among large, medium, small and microenterprises that are located in the province of Azuay. From those 2,366 active companies, 2034 are located in the city of Cuenca, 1486 are limited companies, 547 are anonymous companies, and 1 is a mixed economy company [4].

Following this significant change in the accounting regulations of Ecuadorian companies, under the control of the Superintendencia de Compaías, Valores y Seguros, the idea of investigating the impact of IFRS on net worth is evident considering that "it represents the total of the contributions or quotas that associates of the associative company have paid in money" ([5], p.193).

\section{Methodology}

The research was done considering the Positive Theory of Accounting that mentions that "positivism was legitimized as hegemonic thinking because of its scopes to reflect the business world, achieve instrumental efficiency, and manipulate reality in a capitalist context urged by reliable, truthful, and useful figures" ([6], p.220) besides "it fits better to reality than the utility paradigm which is focused on the relevant information for investment and basically defended in the conceptual framework" ([7], p.100).

The companies data were obtained from the Superintendencia de Compaías, Valores y Seguros website, specifically from the 2016 Business Ranking Report, in which, a total of 2034 companies are registered in Cuenca city where 134 correspond to anonymous companies between medium and large ones which are object of the present study.

With a confidence level of $95 \%$ and a margin of error of $6 \%$, a sample of 89 companies was obtained after the application of the following finite sample formula:

$$
n=\frac{z^{2} * N * P * Q}{E^{2} N+z^{2} * P * Q} .
$$

These selected companies cover several economic activities, among which, the following are mainly observed: Wholesale and Retail Trade, Automotive Vehicle and Motorcycle Repair with 31\%, followed by the Manufacturing Industries activity with $27 \%$ and, in little participation, activities of Construction, Information and Communication, Administrative and Support Services, Education and Other Activities Services with 1\%.
Table 2. Distribution of anonymous companies from the sample according to economic activity

\begin{tabular}{|l|c|c|}
\hline ECONOMIC ACTIVITIES & $\begin{array}{c}\text { NO. OF } \\
\text { COMPANIES }\end{array}$ & $\%$ \\
\hline $\begin{array}{l}\text { Wholesale and retail trade; automobile and } \\
\text { motorcycle repair. }\end{array}$ & 28 & $31 \%$ \\
\hline Manufacture industries & 24 & $27 \%$ \\
\hline Transportation and storage & 10 & $11 \%$ \\
\hline Financial and Insurance service & 5 & $6 \%$ \\
\hline Mining and quarry activities & 4 & $4 \%$ \\
\hline Real estate & 4 & $4 \%$ \\
\hline Accommodation and food service & 3 & $3 \%$ \\
\hline $\begin{array}{l}\text { Professional, Scientific, and Technical } \\
\text { service }\end{array}$ & 3 & $3 \%$ \\
\hline $\begin{array}{l}\text { Human health care and social assistance } \\
\text { service }\end{array}$ & 3 & $3 \%$ \\
\hline Information and communication & 1 & $1 \%$ \\
\hline Administrative and support service & 1 & $1 \%$ \\
\hline Education & 1 & $1 \%$ \\
\hline Construction & 89 & $1 \%$ \\
\hline Other activities and services & $1 \% \%$ \\
\hline TOTAL & 3 & $1 \%$ \\
\hline
\end{tabular}

Source: Self elaboration with data obtained from the Superintendencia de Compaías, Valores y Seguros

Once the sample was calculated, the statements of financial position and comprehensive income statements from years corresponding to the transition period of 89 companies were downloaded from the Superintendencia de Compaías, Valores y Seguros website. In addition, information about the business name, address, file, RUC, year, and whether they were developed under NEC or IFRS was extracted. With the obtained data, the anonymous companies were divided according to the economic activity and the respective transition periods to obtain global data.

\section{Theoretical Framework}

The research applies the Positive Theory of Accounting that consists of obtaining conclusions objectively from the observations of economic facts. It is based on real investigations leaving value judgments aside [8].

The study also implies the analysis of financial statements that are "documents that summarize the economic and financial information of the companies on the basis of the applicable accounting regulations" ([9], p.91), specifically the Statement of Financial Position "which is intended to show the nature of the company's economic resources, as well as the rights of creditors and the participation of owners or shareholders." ([10], p. 172). According to the IFRS, the Worth "is the residual part of the entity's assets, after deducting all its liabilities." ([11], p. 16).

The financial statements are analyzed through the horizontal or "dynamic analysis which is based on the study or analysis of financial statements from several years, in order to observe the changes or modifications that are experienced in the values of the business" ([12], Pp. 46). A vertical or static analysis was also carried out. "This one is performed with the financial statements of a period." ([12], p.46). 


\section{Results}

The results are presented in sections, starting from a global assessment of the impact caused by economic activity to the net shareholder's worth. Subsequently, an assessment of assets and liabilities is presented, and it ends with the evaluation of a direct impact on financial accounts.

\subsection{Impact by Activity of IFRS on Net Worth}

During the transition year 2010, the anonymous companies belonging to Mining and Quarrying business, registered a 4792\% increase in Net Worth due to the fact that the legal reserve account increased by $5501 \%$, equivalent to $\$ 37,279,582,13$. In addition, the Asset increased by $11 \%$, corresponding to $\$ 3,856,731.96$, with Cash and Cash Equivalents accounting for the highest growth at $3246 \%$, equivalent to $\$ 71,064.74$. It is also worth mentioning that for the transitional year 2011, the aforementioned activity registered a value of - \$158,660.44 in the accounting account Cumulative Results for the First Time Adoption of IFRS. These results made this account one of the most significant in equity.

In the same period, the activity of Financial and Insurance Activities recorded a decrease of $18 \%$ in Net Equity due to the fact that, in 2011, its Facultative Reserves decreased by $-100 \%$ which was equivalent to - \$2,675,080.28. This meant that in 2010, the NEC registered \$2,675.363,32 in Facultative Reserves, while in the following period, it presented \$283.04 with the adoption of IFRS. In the meantime, the accounting account, Cumulative Results for the First Time Adoption of IFRS reflected a value of - \$1,794,833.44 by 2011 .

In the transitional year 2011, the Real Estate activity registered a $4241 \%$ increase in Net Equity, equivalent to $\$ 27,455,273.93$. By this period, the Members' contributions increased by $33 \%$, equivalent to $\$ 150,400$. The Voluntary Reserve was increased by $100 \%$ equivalent to $\$ 394,130.36$. The Capital Reserve increased by $100 \%$ equal to \$ 256,194.18. Besides the Accumulated Results for First Time Adoption of IFRS presented a value of $\$ 26,502,496.23$. The Asset increased by 258\%, equivalent to $\$ 26^{\prime} 440,454.63$, due to $890 \%$ increase in Property, Plant and Equipment equivalent to \$ 29'115,557.83. On this matter, IAS 16 Property, Plant and Equipment points out the costs that must be considered in measuring an item of property, plant and equipment at the time of recognition. It indicates that "it will include the costs of its location's dismantling, removal or rehabilitation when they constitute obligations in which the entity incurs as a consequence of the installation of the element" ([13], p. 969).

During this period, the Information and Communication activity reduced its Net Worth by $-44 \%$, despite the fact that its Capital and Reserves have remained intact; however, the Accumulated Losses account of the prior years increased by $27 \%$ equal to $\$ 1 ' 197,195,29$. In addition, the Asset grew only $7 \%$, equivalent to $\$ 193,210.59$, because Inventories and other current assets decreased by $-100 \%$, which means that after the adoption of IFRS these two accounts no longer present assets.

Table 3. Sum of Net Worth by economic activity, before and after the application of IFRS

\begin{tabular}{|c|c|c|c|c|}
\hline ECONOMIC ACTIVITY & 2009-NEC & $2010-$ IFRS & DIFFERENCE & $\%$ \\
\hline Wholesale and retail trade; automobile and motorcycle repair. & $23,348,802,04$ & $25,177,665,64$ & $1,828,863,60$ & $8 \%$ \\
\hline ECONOMIC ACTIVITY & 2010-NEC & 2011- IFRS & DIFFERENCE & $\%$ \\
\hline Mining and quarry activities & $792,055,77$ & $38,749,304,13$ & $37,957,248,36$ & $4792 \%$ \\
\hline Professional, Scientific, and Technical service & $5,241,365,09$ & $10,217,848,08$ & $4,976,482,99$ & $95 \%$ \\
\hline Manufacture industries & $145,398,054,22$ & $204,379,281,08$ & $58,981,226,86$ & $41 \%$ \\
\hline Wholesale and retail trade; automobile and motorcycle repair & $65,914,632,61$ & $89,498,266,77$ & 23,583,634,16 & $36 \%$ \\
\hline Transportation and storage. & $2,274,943,19$ & $2,274,943,19$ & 0,00 & $0 \%$ \\
\hline Financial and Insurance service & $14,466,982,55$ & $11,875,486,29$ & $-2,591,496,26$ & $-18 \%$ \\
\hline ECONOMIC ACTIVITY & 2011-NEC & 2012- IFRS & DIFFERENCE & $\%$ \\
\hline Real estate & $647,336,09$ & $28,102,610,02$ & $27,455,273,93$ & $4241 \%$ \\
\hline Mining and quarry activities & $1,195,412,26$ & $3,878,036,11$ & $2,682,623,85$ & $224 \%$ \\
\hline Accommodation and food service & $3,555,837,59$ & $11,065,606,20$ & $7,509,768,61$ & $221 \%$ \\
\hline Construction & $331,618,65$ & $1,000,958,87$ & $669,340,22$ & $202 \%$ \\
\hline Administrative and support service & $3,031,90$ & $8,101,47$ & $5,069,57$ & $167 \%$ \\
\hline Human health care and social assistance service & 4,368,846,57 & $11,312,606,56$ & $6,943,759,99$ & $159 \%$ \\
\hline Transportation and storage & $1,852,551,05$ & $4,151,435,00$ & $2.298,883,95$ & $124 \%$ \\
\hline Manufacture industries & $10,788,231,36$ & $22,476,349,00$ & $11,688,117,64$ & $108 \%$ \\
\hline Professional, Scientific, and Technical service & 4,880,970,01 & $8,127,461,37$ & 3,246,491,36 & $67 \%$ \\
\hline Other activities and services & $820,603,86$ & $1,121,681,18$ & $301,077,32$ & $37 \%$ \\
\hline Education & $570,729,54$ & $747,284,42$ & $176,554,88$ & $31 \%$ \\
\hline Wholesale and retail trade; automobile and motorcycle repair & 7,841,769,82 & $9,842,955,06$ & $2,001,185,24$ & $26 \%$ \\
\hline Financial and Insurance service & $-1,938,079,44$ & $1.847,269,31$ & $-90,810,13$ & $5 \%$ \\
\hline Information and communication & $766,754,62$ & $428,752,50$ & $-338,002,12$ & $-44 \%$ \\
\hline
\end{tabular}

Source: Self elaboration with data obtained from the Superintendencia de Compaías, Valores y Seguros. 
Table 4. Net Assets before and after IFRS

\begin{tabular}{|c|c|c|c|}
\hline & 2009-NEC & $2010-$ IFRS & DIFERENCE \\
\hline Net Assets & $23,348,802,04$ & $25,177,665,64$ & $1,828,863,60$ \\
\hline & $\mathbf{2 0 1 0 - N E C}$ & $\mathbf{2 0 1 1}-\mathbf{I F R S}$ & DIFERENCE \\
\hline Net Assets & $233,607,941,22$ & $356,536,700,54$ & $122,928,759,32$ \\
\hline Net Assets & $\mathbf{2 0 1 1 - N E C}$ & $\mathbf{2 0 1 2}$ - IFRS & DIFERENCE \\
\hline
\end{tabular}

Source: Self Elaboration with data obtained from the Superintendencia de Compaías, Valores y Seguros.

From the anonym companies taken as a sample it is possible to see, in a general way, an average rise of $84 \%$. During the year 2011, Mining and Quarry activities registered a rise of $4792 \%$ in its Net Assets and in the Asset the account that outstands is the one corresponding to Cash and Equivalent to Cash, besides that it might have been influenced by the approval of the Environmental Law for mining activities in the Republic of Ecuador [14], which mentions that the mining holders 'must take strict precautions in order to avoid the soil, water, air and Biota pollution, or the places where they are scattered...by building facilities such as dumps, landfills, tailings deposits or dams, or other technically designed and built facilities ([15], p. 44).

In the year 2012, real estate activity registered a rise of $4241 \%$ in its Net Assets equivalent to \$27,455,273,93 highlighting that the same year it was included the financial account accumulated Results by adopting for the first time the ones from IFRS showing an amount of $\$ 26,502,496,23$. Regarding the Assets, the account which presented a greater rise was the Property, Factory and Equipment.

In the same year, concerning the Information and Communication activities, it was possible to realize that the Net Assets diminished 44\% equivalent to $-\$ 338,002.12$ due to the rise of $100 \%$ in non-checking liabilities because of benefits for employees. Concerning this subject, the IAS 19 mentions that the benefits for employees include salary, payments, and social security payments, rights for granted permissions and granted absence for illness, participation in profits and incentives, and non-monetary benefits for current employees ([15], p. 1025). In addition, such an activity could have been influenced by the approval of 'Organic Law pro defense of Labor Rights’ [16].

Ever since IFRS regulations were adopted, all the adjustments caused by IFRS 13 Measurement of Reasonable Value especially in Property, Factory and Equipment, were reflected in the financial account Accumulated Results by adopting for the first time the ones from IFRS. The economic activity of wholesales and retailer Trade, automobile and motorcycle repair, presented a superior amount in the account Accumulated Results by adopting for the first time the ones from IFRS because its assets were undervalued, which means that after the adoption of IFRS 13 its Assets presented a higher monetary value compared to the one registered in the books. While in the Mining and Quarry activities there is a negative value since its Assets were overvalued, meaning the prices of the goods were registered in books with a higher price compared to the market.

Along the transition period, the Asset had an average rise of $81 \%$. Office and support activities Asset increased in a $383 \%$ corresponding to $\$ 38,293.16$, since there is a rise of $621 \%$ in the account Cash and Cash Equivalent corresponding to $\$ 26,316.60$, in NIC 7 Cash Flow Statement shows that 'Every entity presents its cash flow coming from operation, investment and financing in a way that it might be more suitable according to the nature of its activities' ([17], p. 876).

Table 5. Accumulated Results after Adopting IFRS for the first time for economic activities

\begin{tabular}{|l|c|c|}
\hline ECONOMIC ACTIVITY & IFRS \\
\hline Wholesale and retail Trade; automobile and motorcycle repair & $124,518,887,47$ \\
\hline Real Estate & $26,502,496,23$ \\
\hline Manufacture industries & $25,656,683,57$ \\
\hline Human health care and social assistance service & $6,181,495,40$ \\
\hline Accommodation and food service & $6,181,495,40$ \\
\hline Transportation and storage service & $2,724,163,81$ \\
\hline Financial and insurance service & $2,185,458,96$ \\
\hline Education & $85,149,68$ \\
\hline Construction & $646,010,86$ \\
\hline Mining and quarry activities & $13 \%$ \\
\hline Professional, scientific and technical service & $-158,660,44$ \\
\hline TOTAL & $893,437,82$ \\
\hline
\end{tabular}

Source: Self Elaboration with data obtained from the Superintendencia de Compaías, Valores y Seguros. 
Table 6. Summation for the Assets in economic activities before and after the implementation of IFRS

\begin{tabular}{|l|c|c|c|c|}
\hline ECONOMIC ACTIVITY & NEC & IFRS & DIFERENCE & \% \\
\hline Administrative and support service & $10,007,92$ & $48,301,08$ & $38,293,16$ & $383 \%$ \\
\hline Real estate & $10,237,415,82$ & $36,677,870,45$ & $26,440,454,63$ & $258 \%$ \\
\hline Human health care and social service & $6,119,686,03$ & $17,056,363,23$ & $10,936,677,20$ & $179 \%$ \\
\hline Education & $921,282,05$ & $1,312,739,61$ & $391,457,56$ & $42 \%$ \\
\hline Construction & $2,348,026,00$ & $3,248,005,75$ & $899,979,75$ & $38 \%$ \\
\hline Transportation and storage service & $10,409,199,12$ & $14,211,633,94$ & $3,802,434,82$ & $37 \%$ \\
\hline Manufacture industries & $362,209,952,13$ & $468,854,502,28$ & $106,644,550,15$ & $29 \%$ \\
\hline Mining and quarry activities & $39,347,272,05$ & $48,735,929,25$ & $9,388,657,20$ & $24 \%$ \\
\hline wholesales and retailer Trade; automobile and motorcycle repair & $316,238,339,79$ & $367,784,001,29$ & $51,545,661,50$ & $16 \%$ \\
\hline Professional, scientific and technical service & $35,552,392,99$ & $40,830,474,58$ & $5,278,081,59$ & $15 \%$ \\
\hline Other services & $4,348,338,57$ & $5,002,009,04$ & $653,670,47$ & $15 \%$ \\
\hline Information and communication & $2,697,970,58$ & $2,891,181,17$ & $193,210,59$ & $7 \%$ \\
\hline Financial and insurance service & $21,156,696,94$ & $22,408,819,26$ & $1,252,122,32$ & $6 \%$ \\
\hline
\end{tabular}

Source: Self Elaboration with data obtained from the Superintendencia de Compaías, Valores y Seguros.

In the meantime, in Real Estate there was a rise of a $258 \%$ corresponding to $\$ 26,440,454.63$ since in such an account Property, Factory and Equipment increased in an $890 \%$ which is $\$ 29,115,557.83$.

The IFRS 16 Property, Plant and Equipment shows that 'The entity will measure the account of property, plant and equipment acquired in exchange of one or various non-monetary assets, or a combination of monetary and non-monetary assets, for its reasonable value' ([13], p. 969), considering that in the IFRS 13 Measure of the Reasonable Value sets that 'a reasonable value measure will be supposed the asset sale transaction or the liability transfer to take place: in the main asset or liability market, or in absence of a main market, in the most suitable market for the asset or liability' ([18], p. 674).

In the Financial and Insurance services it must be observed that the Asset rises only 6\% corresponding \$ 1,252,122.32 since the intangible Assets decrease in $-100 \%$ which is $\$ 4,156,638.82$. The NIC 38 Intangible Assets establishes that an intangible will be recognized if 'it's probable that the future economic benefits that have been attributed to the asset itself flow to the entity, and the cost of the asset can be measured in a trustworthy way' ([19], p. 1389).

The Asset financial accounts, which during the years of transition presented a greater rise are: other checking financial assets with $357 \%$ corresponding to \$3,657, 629.16. Non-checking Assets kept for sale with 206\% which is $\$ 104,454.28$, whose reference lies in the IFRS 5, non-checking Assets kept for sale and discontinued operations, which in the paragraph 6 says that it will be considered as a non-checking Asset for sale as long as 'its amount in the books will be recovered fundamentally through a sale transaction' ([20], p. 244).

Property, Plant and Equipment with 104\% corresponding to \$109, 070,786.29, which in the NIC 16 Property, plant and equipment, in the paragraph 6 , section $A$, says that tangible assets are the ones that 'have an entity for its use in the production or supply of goods and services, to rent other people, or administrative purposes and are meant to be used for more than a period' ([13], p. 972).

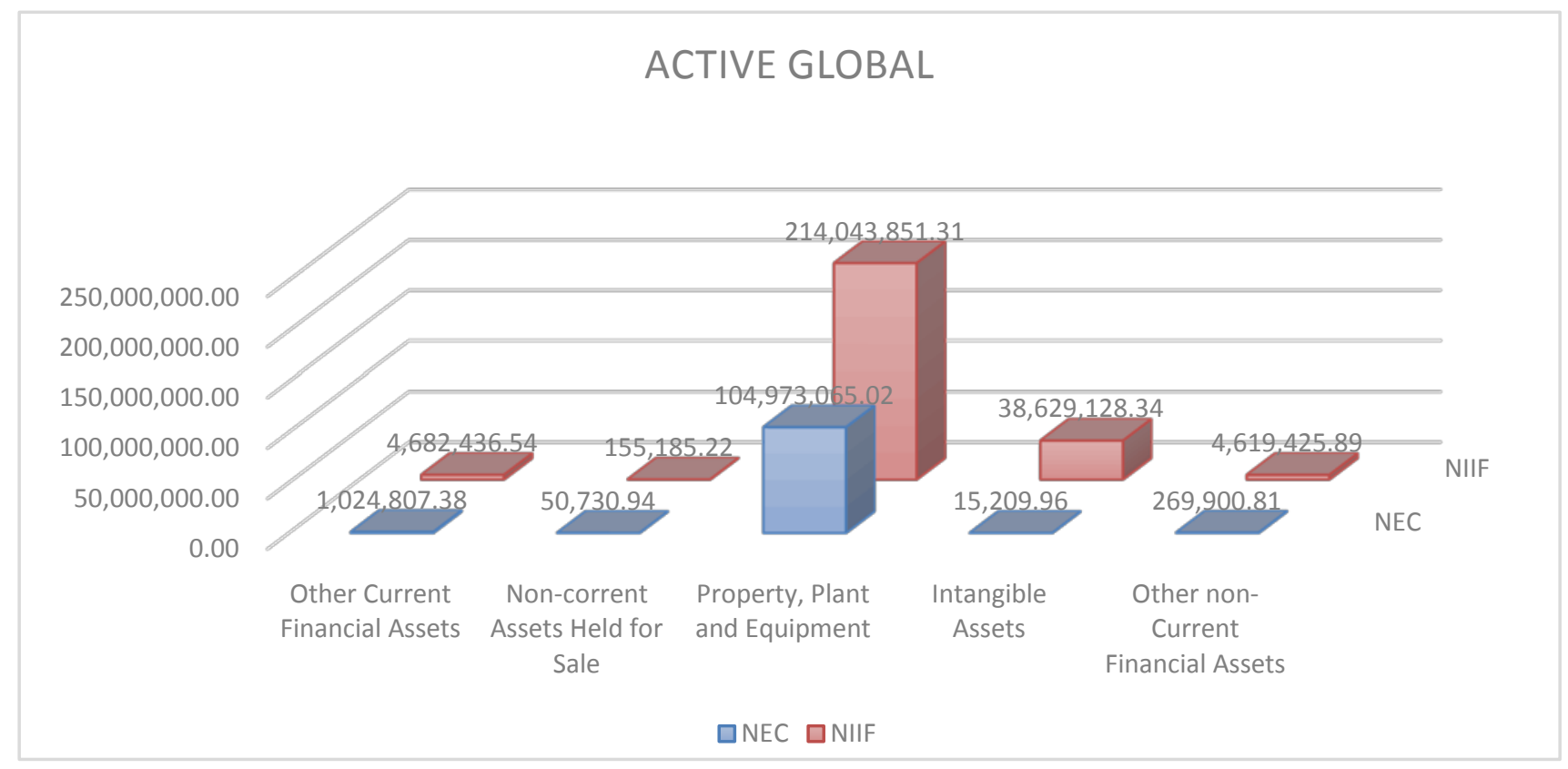

Source: Self Elaboration with data obtained from the Superintendencia de Compaías, Valores y Seguros.

Diagram 1. Financial Accounts of the Asset with the greatest variation 
Regarding the Intangible Assets there is a rise of 253,873\% corresponding to \$38,613,918.38, considering that in the NIC 38 Intangible Assets says that 'an intangible asset is one identified as non-monetary with no physical appearance' ([19], p. 1380) and besides that, an intangible asset will be measured by its initial cost and 'the recognition of the costs in values in the books of an intangible asset will end when the asset is in the necessary place and conditions to operate in manner expected by the management'([19], p. 1390).

Finally, the account other non-Current Financial Assets will rise in a $1612 \%$ which is $\$ 4,349,525.08$, it is mentioned in the IFRS 9 Financial Instruments establishes that 'A financial asset will be measured according to the reasonable price with changes in the results unless it is measured according to its redeemed cost' ([21], p. 377).

In a general way, Liability after the implementation of IFRS registers an average rise of $59 \%$ in the Office and Support activities, they present a rise in the Liability $476 \%$ corresponding to $\$ 33,223.5$, since the account Checking
Liability due to benefits for employees go up to $1983 \%$ which is \$6,744,54. Human health care and social services had a rise in the liability of $228 \%$ corresponding to $\$ 3,992,917.21$ since the Accounts and documents to be paid rose in a $551 \%$ which is $\$ 1,506,542.20$.

In the meantime, Mining and Quarry activities show a decrease of $-84 \%$ in the liability corresponding to $\$ 31,251,215.01$, considering that the accounts checking and non-checking Stocks decreased in a $-100 \%$, since when the Financial Estates were presented under the NEC the accounts mentioned before present costs of \$ 19,750.39 and \$ $166,779.78$ respectively, but when the IFRS were adopted, there were no costs in such accounts, being the liability accounts the ones which present a decrease compared to the rests. Regarding professional, scientific and technical services, there is a decrease of $-12 \%$ in its liability corresponding to $-\$ 3,078,606.81$ due to the fact that the Accounts and non-checking documents to be paid diminished in a $-60 \%$ equivalent to $-\$ 7,591,791.39$.

Table 7. Sum of the liabilities in economic activity before and after the implementation of IFRS

\begin{tabular}{|c|c|c|c|c|}
\hline ECONOMIC ACTIVITY & NEC & IFRS & DIFERENCE & $\%$ \\
\hline Administrative and support service & $6,976,02$ & $40,199,61$ & $33,223,59$ & $476 \%$ \\
\hline Human health care and social assistance service & $1,750,839,46$ & $5,743,756,67$ & 3,992,917,21 & $228 \%$ \\
\hline Education & $350,552,51$ & $565,455,19$ & $214,902,68$ & $61 \%$ \\
\hline Manufacture industries & $187,471,956,12$ & $241,998,872,20$ & $54,526,916,08$ & $29 \%$ \\
\hline Information and communication & $1,931,215,96$ & $2,462,428,67$ & $531,212,71$ & $28 \%$ \\
\hline Transportation and storage service & $6,281,704,88$ & $7,785,255,75$ & $1.503 .550,87$ & $24 \%$ \\
\hline Construction & $2,016,407,35$ & $2,247,046,88$ & $230,639,53$ & $11 \%$ \\
\hline wholesales and retailer Trade; automobile and motorcycle repair & $212,212,194,04$ & $232,500,369,23$ & $20,288,175,19$ & $10 \%$ \\
\hline Other services & $3,527,734,71$ & $3,880,327,86$ & $352,593,15$ & $10 \%$ \\
\hline Financial and insurance service & $8,627,793,83$ & $8,683,433,01$ & $55,639,18$ & $1 \%$ \\
\hline Mining and quarry activities & $37,359,804,02$ & $6,108,589,01$ & $-31,251,215,01$ & $-84 \%$ \\
\hline Professional, scientific and technical service & $25,582,124,20$ & $22,503,517,39$ & $-3,078,606,81$ & $-12 \%$ \\
\hline Real estate & $9,590,079,73$ & $8,575,260,43$ & $-1,014,819,30$ & $-11 \%$ \\
\hline
\end{tabular}

Source: Self Elaboration with data obtained from the Superintendencia de Compaías, Valores y Seguros.

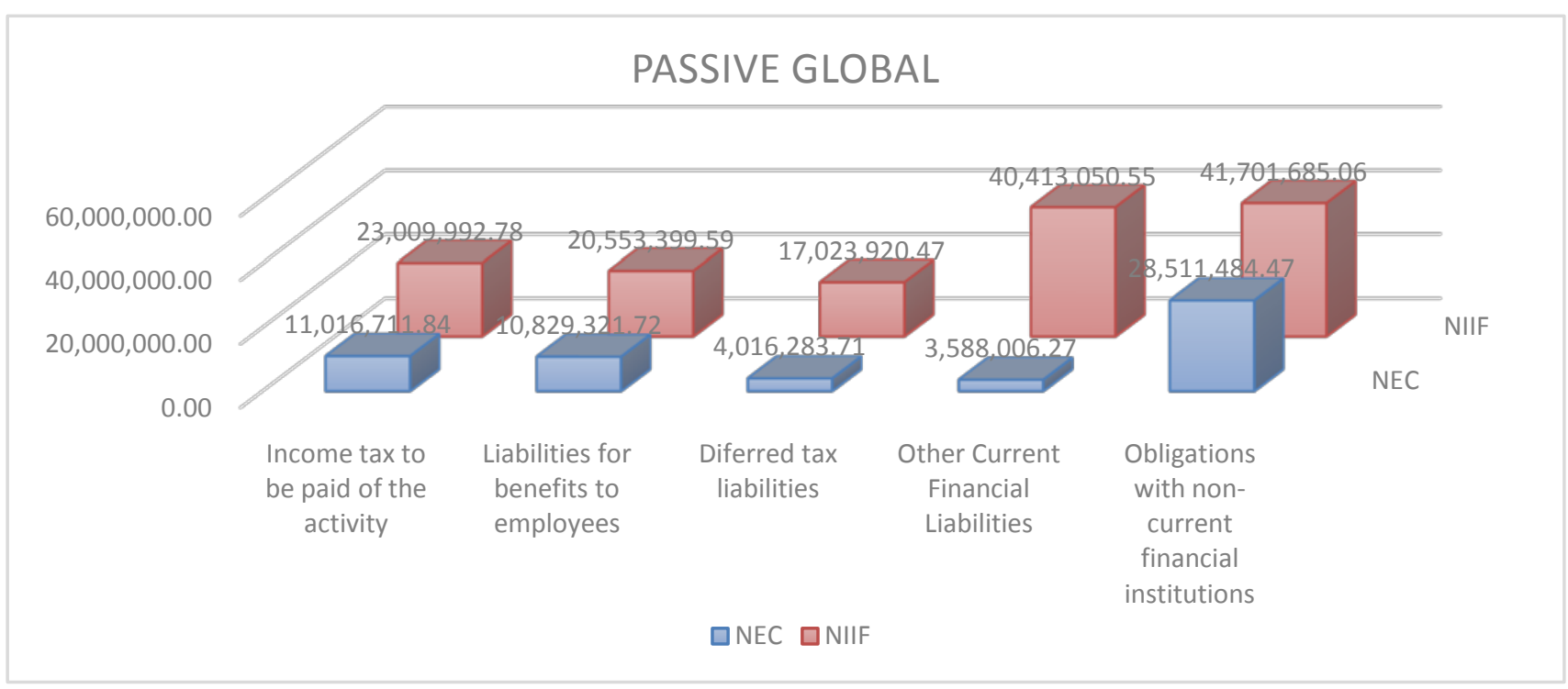

Source: Self Elaboration with data obtained from the Superintendencia de Compaías, Valores y Seguros.

Figure 2. Financial accounts of the most variable liability 
The liability financial accounts which show a bigger impact after the change from NEC to IFRS are: Income tax to be paid of the activity which shows a rise of $109 \%$ corresponding to $\$ 11,993,280.94$, checking liabilities for benefits to employees with a rise of $90 \%$ which is $\$ 9,724,077.87$, keeping in mind that it is being referred to the IFRS 19 Benefits to employees. Liabilities on delayed taxes with a rise of $324 \%$ corresponding to $\$ 13,007,636.76$ which refers to the NIC 12 Income tax in which it is mentioned that 'Liabilities on delayed taxes are the amounts of taxes on the profit to be paid in future periods related to the taxable temporary differences' ([22], p. 929). Regarding to recognition 'An entity must recognize a liability with delayed taxes in all the cases of taxable temporary differences associated to investments in branch offices and associated subsidiaries, branch offices, or with participation in mutual agreements' ([22], p. 943).

Other checking financial liabilities with a rise of $1026 \%$ which is $\$ 36,825,044.28$, the account mentioned before, it is considered as 'Obligation acquired with banks and financial establishments to be paid off within a year deadline starting on the date of financial statements closure' ([12], p. 223). Regarding the Obligations with non-checking financial establishments that show a rise of $46 \%$ corresponding to $\$ 13,190,200.59$.

\section{Discussion and Conclusions}

The net worth, of anonym companies being studied, suffered an important rise in the period of transition after the adoption of IFRS, being an important element the implementation of IFRS 13s Measure of the Reasonable Value that affected the Property financial account mainly, plant and equipment, the reasonable value is defined as 'the price that would be received for selling an asset or paid for transferring a liability in a transaction arranged between market participants on the date of measure' ([23], p. 74). Other changes detected will be explained in the upcoming paragraphs.

During the period since the year of transition 2009 to 2010, the Net Worth rose in an 8\% corresponding to $\$ 1,828,863.60$, considering the rise in the financial account Accumulated Results by Implementing the IFRS for the very first time with a $100 \%$, equivalent to $\$ 173,258.13$, it is important to mention that in the IFRS 1 Implementation of the Financial Information International Regulations for the first time mentions that 'An entity will recognize such adjustments on the date of transition to the IFRS, directly from the accumulated profits' ([24], p. 15), considering that the economic reality of the country in that year registers a GDP of 3,5\% and the inflation rate was 3,33\% (Banco Central del Ecuador, 2017).

Regarding the period from the year of transition 2010 to 2011 , there was a rise of $53 \%$ in the Net Worth which is $\$ 123,040,810.16$ due to the Contribution of the associates' account with a $63 \%$ corresponding to \$2,231,844.00. Mining and quarry activities showed the greatest rise of the Net Worth according to the IFRS 6 Exploring and Evaluation of Mineral Resources which states that in order to measure its assets, it might be included: purchase of rights to explore, topographic, geologic, geo-chemical and physical studies, exploratory drilling, ditch and trench excavation, sample collecting' ([25], p. 267). Considering that the economic reality of the country in that year registers a GDP of 7,8\% and the inflation rate was 5,41\% (Banco Central del Ecuador, 2017).

In the period from the year of transition 2011 to 2012, there was a rise of $165 \%$ in the Net Worth which is $\$ 71,705,918.53$ considering that the account Legal Reserve rose in a $42 \%$ corresponding to $\$ 726,662.80$, the article 297 of the Law of Companies states that, 'a percentage, not inferior than ten per cent, will be taken, intended to form the legal reserve fund, until it reaches at least fifty percent of the social assets' ([13], p. 85). The account Voluntary Reserve went up in a $65 \%$ which is $\$ 1,087,231,57$. Voluntary Reserves 'are made up by voluntary decision of the associates or shareholders' ([25], p. 276). Real Estate activities recorded the greatest rise in its Net Worth, taking into account that the economic reality of the country in that year shows that the GDP was $5,1 \%$ and the inflation 4,16\% [26].

Regarding the Asset, after the implementation of IFRS; in a general way it registers a rise of $27 \%$ equivalent to \$ 217, 465,250.94 highlighting that Office and Support Activities went up majorly compared to the rest of economic activities presenting a rise of 383\% which represents \$38,293.16, also considering that Property, Plant and Equipment registered a superior growth if compared to the rest of accounts with a 104\% corresponding to $\$ 109,070,786.29$. Taking into account that such an account is referred to NIC 16 Property, plant and equipment. It mentions that 'Goods that make up this item must be registered initially according to the cost of purchase or construction, or the reasonable value determined through appraisal, in the case of goods contributed, donated, received, in exchange of debts and similar ones' ([25], p. 200) Besides that, 'An element of properties, plant and equipment that meets the requirements to be recognized as an asset, will be measured by its cost' ([13], p. 975).

Liabilities after the transition from NEC to IFRS rise in a 9\% corresponding to \$46,385,129.09. Office and Support Activities when rising a $476 \%$ representing $\$ 33.223 .5$ show a greater growth of liabilities if compared to the rest of economic activities, having an impact especially in the account Other financial checking liabilities which show a rise of $1026 \%$ corresponding to $\$ 36,825,044.28$ being this one the most important rise if compared to the rest of the financial liability accounts.

\section{References}

[1] Estupiñán, R. (2015). Estados Financieros: básicos bajo NIC-NIIF. Lima: Macro.

[2] Mantilla, S. A. (2015). Estándares/normas internacionales de informaición financiera.

[3] Banco Central del Ecuador. (22 de 05 de 2017). Banco Central del Ecuador. Obtenido de Banco Central del Ecuador: https://www.bce.fin.ec/index.php/component/k2/item/776.

[4] Superintendecia de Compañías, Valores y Seguros. (30 de 08 de 2016). Superintendecia de Compañías, Valores y Seguros. Obtenido de Superintendecia de Compañías, Valores y Seguros: http://appscvs.supercias.gob.ec/rankingCias/rankingCias.zul?id=0 $1 \&$ tipo=2. 
[5] Cardozo Cuenca, H. (2011). Contabilidad de entidades de economía solidaria (4a. ed.). Colombia: Ecoe Ediciones.

[6] Machado Rivera, M. A. (08 de 05 de 2012). Del positivismo a la diversidad epistemológica: un paso necesario para la construcción de pensamiento contable . Universidad de Antioquia; Medellin, 219-237. Obtenido de ProQuest Central:

https://bibliotecavirtual.ups.edu.ec:2598/docview/1679410095?acc ountid=32861.

[7] Sanchez Molina, H., \& Enguidanos Mora, A. (2015). Cambios conceptuales en la contabilidad de los arrendamientos: retos normativos y académicos/Conceptual changes in lease accounting: Regulatory and academic challenges. Revista de Contabilidad; Madrid, 99-113.

[8] Jaramillo, M. O., Buitrago Muñoz, M. A., Cardona Marín, L. M., \& Gaitan Sánchez, M. V. (23 de 07 de 2006). Monografias.com. Obtenido de Monografias.com:

http://www.monografias.com/trabajos34/positivismocontabilidad/positivismo-contabilidad.shtml.

[9] Carrasco Gallego, A., \& Donoso Anes, J. A. (2016). Estados financieros: teoría y casos prácticos. Madrid: Pirámide.

[10] Moreno Fernández, J. A. (2014). Contabilidad superior (4a.ed.) México: Grupo Editorial Patria.

[11] International Accounting Standards Board (2016). Normas Internacionales de Información Financiera para pequeñas y medianas entidades. IFRS Foundation.

[12] Oropeza Martínez, H. (2012). Análisis e Interpretación de la Información Financiera. México: Trillas.

[13] International Accounting Standards Board (2001). NIC 16 Contabilización de Propiedades, Planta y Equipo. IFRS Foundation.
[14] Asamblea Nacional del Ecuador (2009). Reglamento ambiental para actividades mineras en la República del Ecuador. Quito.

[15] International Accounting Standards Board (2001). NIC 19 Beneficios a los Empleados. IFRS Foundation.

[16] Asamblea Nacional del Ecuador. (2012). Ley orgánica para la Defensa de los Derechos Laborales. Quito.

[17] International Accounting Standards Board (2001). NIC 7 Estados de Flujos de Efectivo. IFRS Foundation.

[18] International Accounting Standards Board (2011). NIIF 13 Medición del Valor Razonable. IFRS Foundation.

[19] International Accounting Standards Board (2001). NIC 38 Activos Intangibles. IFRS Foundation.

[20] International Accounting Standards Board (2004). NIIF 5 Activos no Corrientes Mantenidos para la Venta y Operaciones Discontinuadas. IFRS Foundation.

[21] International Accounting Standards Board (2009). NIIF 9 Instrumentos Financieros. IFRS Foundation

[22] International Accounting Standards Board (2001). NIC 12 Impuesto a las Ganancias. IFRS Foundation.

[23] Filgueira Ramos, C. A. (2013). Manual Contable NIIF. Santiago de Chile: Galindo.

[24] International Accounting Standards Board (2009). NIIF 1 Adopción por Primera vez de las Normas Internacionales de Información Financiera. IFRS Foundation.

[25] International Accounting Standards Board (2009). NIIF 6 Exploración y Evaluación de Recursos Minerales. IFRS Foundation.

[26] Superintendencia de Compañías, Valores y Seguros. (2008). Superintendencia de Compañías, Valores y Seguros. Obtenido de Superintendencia de Compañías, Valores y Seguros: Superintendencia de Compañías, Valores y Seguros. 